\title{
The Chemical Composition of Ground Water in Observational Water Vents in the Petropavlovsk Geodynamic Test Site: The Classification and Effects of Large Earthquakes
}

\author{
G. N. Kopylova ${ }^{a}$ * , N. V. Guseva ${ }^{b}$, Yu. G. Kopylova ${ }^{b}$, and S. V. Boldina ${ }^{a}$ \\ ${ }^{a}$ Kamchatka branch of Geophysical Survey of the Russian Academy of Sciences, Bul'var Piipa, 9, \\ Petropavlovsk-Kamchatskii, 683006 Russia \\ ${ }^{b}$ FGAOU VO Tomsk National Research Polytechnic University, prospect Lenina, 30, Tomsk, 634050 Russia \\ *e-mail: gala@emsd.ru \\ Received August 30, 2017
}

\begin{abstract}
This paper considers the chemical composition and classification of ground water at seven flowing wells and four springs using materials from the 2014 hydrogeochemical sampling and from continuous observations conducted by the Kamchatka Branch of the Geophysical Survey of the Russian Academy of Sciences (KB GS RAS) in 1989-1999. We estimated the saturation of ground water discharges at individual vents with alumosilicate, carbonate, and sulfate secondary minerals, following the behavior of saturation over time. We have found that the ground water undergoes an increase in the saturation with secondary minerals during large earthquakes that produced shaking of intensity I $=5-6$ on the MSK-64 scale. Such changes in the saturation of ground water with secondary minerals are less pronounced during the precursory periods before earthquake occurrence. We discuss desirable future developments of the observational system at wells and springs in order to look for new types of hydrogeochemical precursors to earthquakes.
\end{abstract}

DOI: $10.1134 / \mathrm{S} 0742046318040048$

\section{INTRODUCTION}

Since 1977 the chemical composition of ground water discharged by flowing wells and springs has been measured in the Petropavlovsk Geodynamic Test Site area, Kamchatka in the search for hydrogeochemical precursors for, and research on, earthquake prediction. The changes in the concentrations of macrocomponents in the composition of ground water and free gas were found to contain anomalies related to large local earthquakes, including hydrogeochemical precursors predating earthquake occurrence by a few weeks to a few months (Kopylova et al., 1994; Kopylova and Boldina, 2012; Khatkevich and Ryabinin, 2004). The mechanisms of such anomalies are still insufficiently known in their geochemical aspect. This issue should be studied comprehensively, because an adequate understanding of the processes that operate in the production of hydrogeochemical seismicity effects using observations of the composition of ground water will facilitate the optimal arrangement of specialized observations at wells and springs in seismic regions.

The study of anomalies in the composition of ground water from wells and springs during earthquakes based on fundamental patterns in their formation in the water-rock systems may enable us to find a meaningful explanation. The first attempt at such an approach was demonstrated in (Kopylova et al., 2014), where an anomaly of water composition at the Moroznaya-1 well during the March 2, 1992, M 6.9 earthquake was analyzed using methods of equilibrium thermodynamics and the analysis of elementary chemical reactions that are occurring in the waterrock system (Garrels and Christ, 1965). Assuming that the initial products of such reactions would be rockforming minerals and water, while the end products would be secondary minerals, as well as ions and neutral molecules that enter ground water; and further, making use of a quantitative parameter, viz., the index of disequilibrium of ground water in relation to secondary minerals (or the A index after Zverev (1982)), we showed changes in the saturation of water with secondary minerals, not only during the post-seismic phase, but also during the precursory periods of earthquakes. The equations that describe interactions between water and alumosilicates, carbonate, and sulfate minerals, their main thermodynamic parameters, and a description of the method can be found in (Kopylova et al., 2014, http://www.kscnet.ru/ivs/publication/volc_day/2014/art29.pdf). This approach to the interpretation of observations of the chemical composition of ground water is intended for the development of a hydrogeochemical method for use in the search for earthquake precursors, in particular, for 


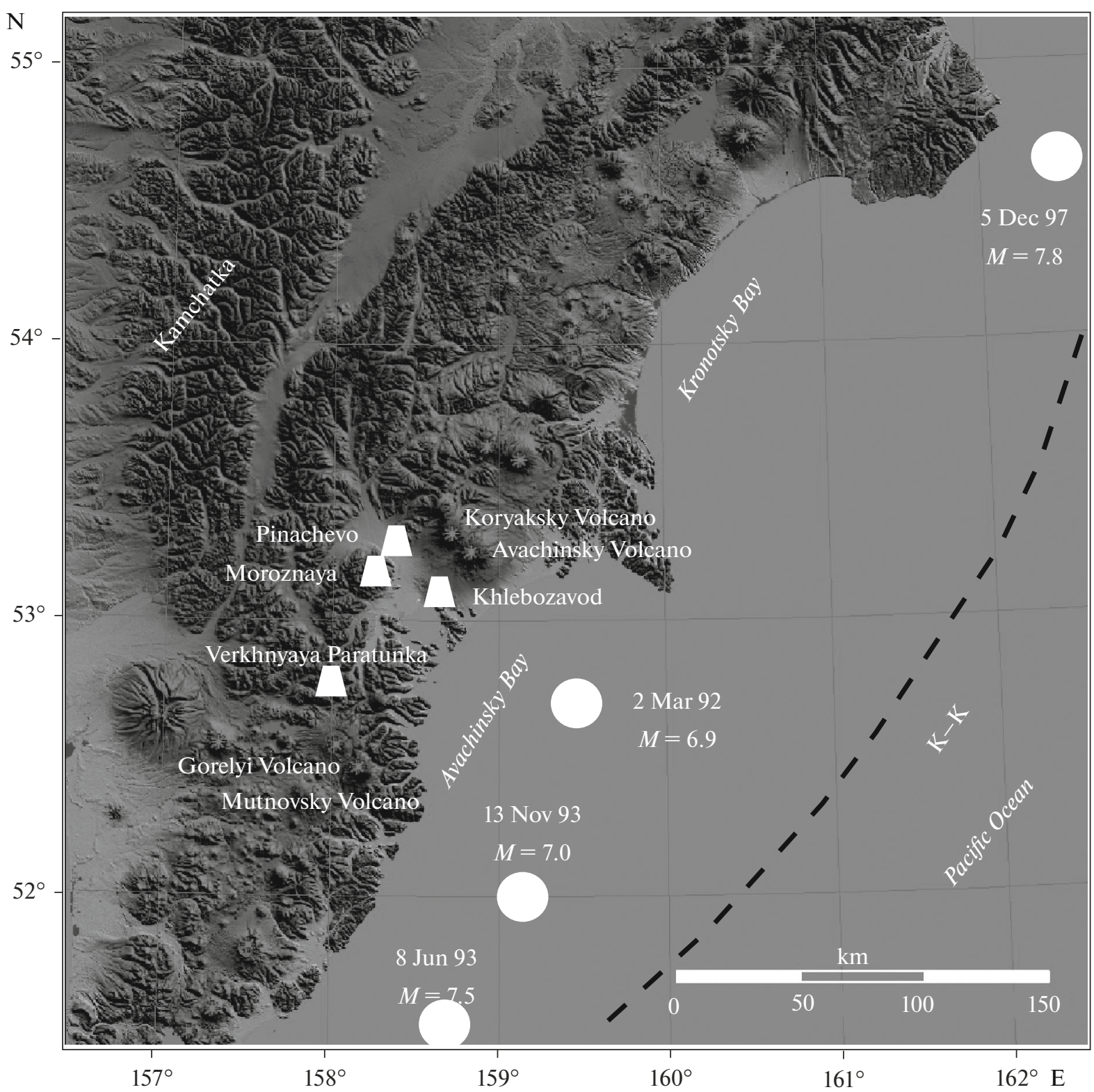

Fig. 1. A sketch map showing the hydrogeochemical stations operated by the KB GS RAS in the area of the Petropavlovsk Test Site and epicenters of large earthquakes (circles) with indication of their dates (in the dd.mm.yyyy format) and magnitude $M$. KK marks the axis of the Kuril-Kamchatka deep-sea trench, which is the boundary between the Pacific oceanic plate and the Eurasian continental plate.

finding the set of informative parameters for each observing well.

We investigated the areas where hydrogeochemical stations (Pinachevo, Verkhnyaya Paratunka, Moroznaya, and Khlebozavod) were situated (Fig. 1), sampling water from 11 permanent water discharges. This paper presents data on chemical water composition for the GK-1 well and four springs at the Pinachevo station, for the Moroznaya-1 (M-1) and G-1 (Khlebozavod station) wells and for four wells at the Verkhnyaya Paratunka station (GK-5, GK-15, GK-17, and GK-44) based on the 2014 sampling survey and on materials of hydrogeochemical observations carried out by the Kamchatka Branch of the Geophysical Survey of the Russian Academy of Sciences (KB GS RAS) in 1989-1999.

The chemical analysis of the 2014 water samples with determination of macro- and micro-components was carried out at the Problem-Specific Hydrogeochemical Research Laboratory of the Voda Science and Education Center, Tomsk Polytechnic University. The results of these analyses are presented in Tables 1 and 2, with diagrams of chemical composition being shown in Fig. 2. 

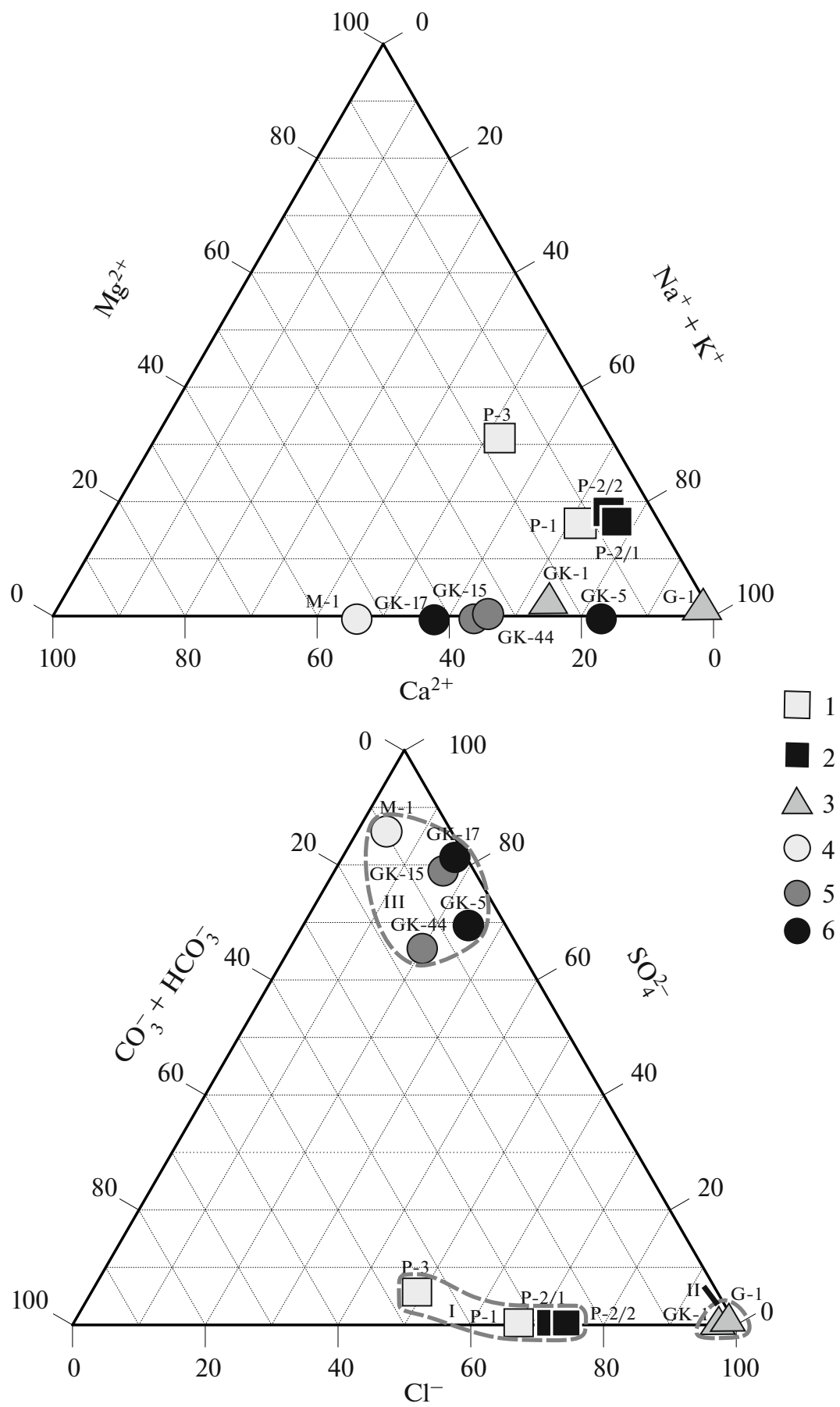

Fig. 2. Diagrams of chemical composition for waters from springs and flowing wells in the Petropavlovsk Test Site area. (1) fresh cold pore-fissure and fissure waters from springs P-3 and P-1, Pinachevo station; (2) fresh subthermal fissure waters from springs P-2/1 and P-2/2, Pinachevo station; (3) saline subthermal fissure and fissure-vein waters from well GK-1, Pinachevo station and from the G-1 well, Khlebozavod station; (4) ultrafresh subthermal fissure-vein waters from the M-1 well, Moroznaya station; (5) fresh subthermal fissure-vein waters from the GK-44 and GK-15 wells, Verkhnyaya Paratunka station; (6) brackish thermal fissure-vein waters from wells GK-17 and GK-5, Verkhnyaya Paratunka station; I, II, III water sets identified here (see text).

The saturation of ground water with main rockforming minerals at permanent water discharges was estimated by plotting the data in diagrams of stability fields for alumosilicate minerals (Fig. 3) and calculating the saturation index (SI) with respect to alumosilicate, carbonate, and sulfate minerals at a temperature of $25^{\circ} \mathrm{C}$ (Garrels and Christ, 1965) (Fig. 4): SI $=$ $\log (\mathrm{Q} / K \mathrm{p})$, where $Q$ is the reaction quotient or the ratio of the actual product of the activities for reaction products to the actual product of activities in initial substances, and $K \mathrm{p}$ is a reaction constant. Positive SI values show that the water is saturated with secondary 


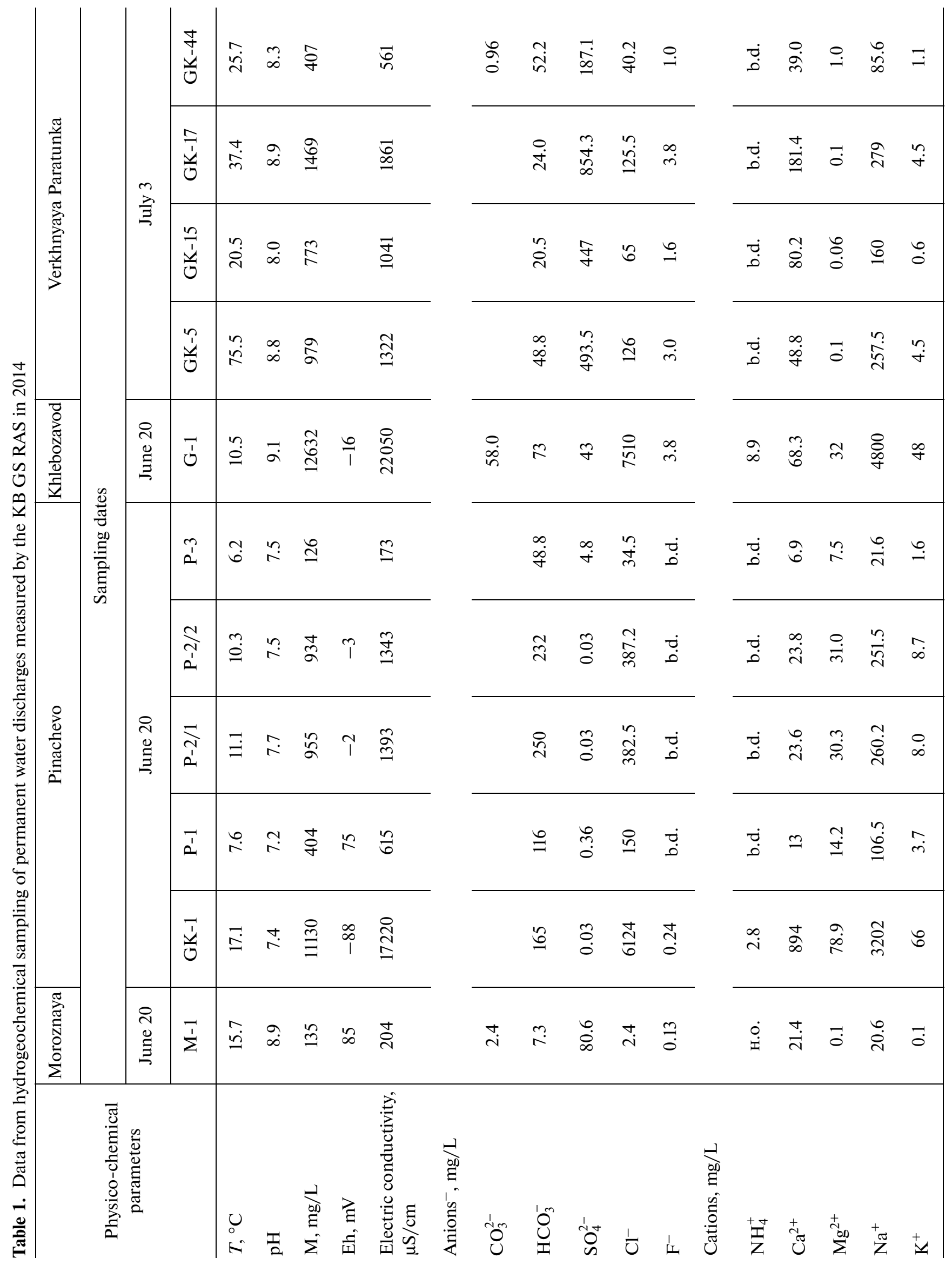




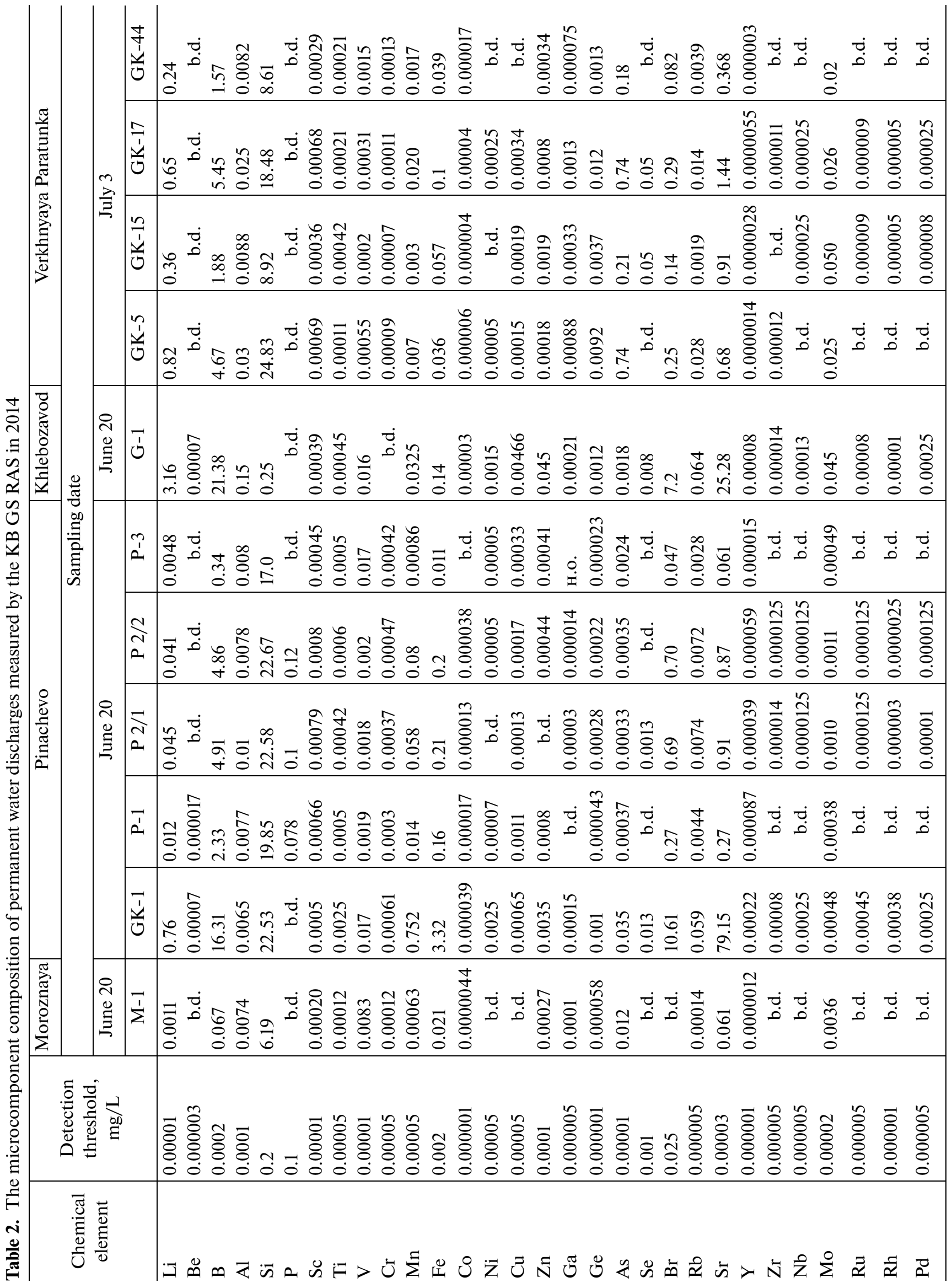




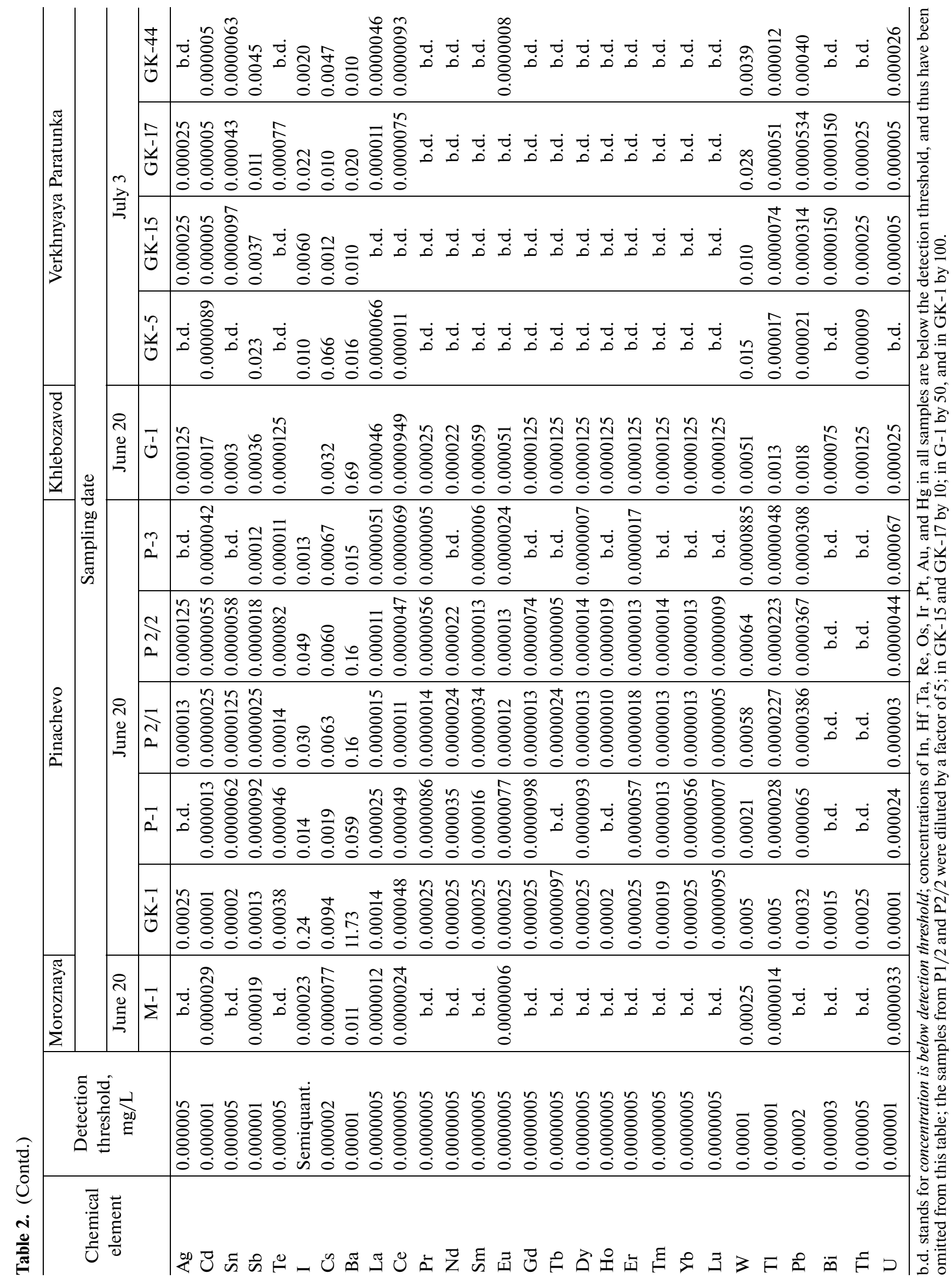


(a)

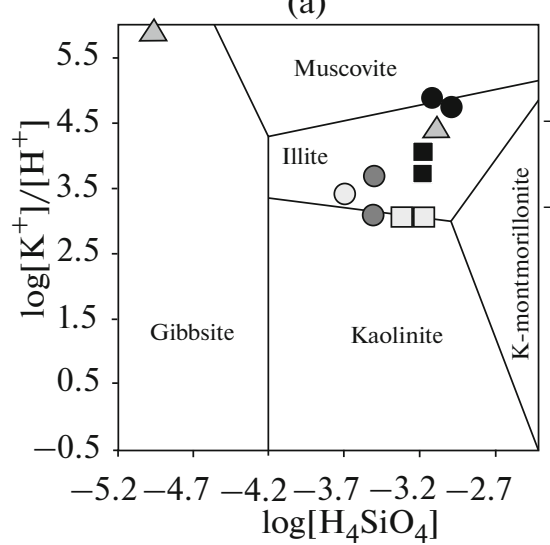

(d)

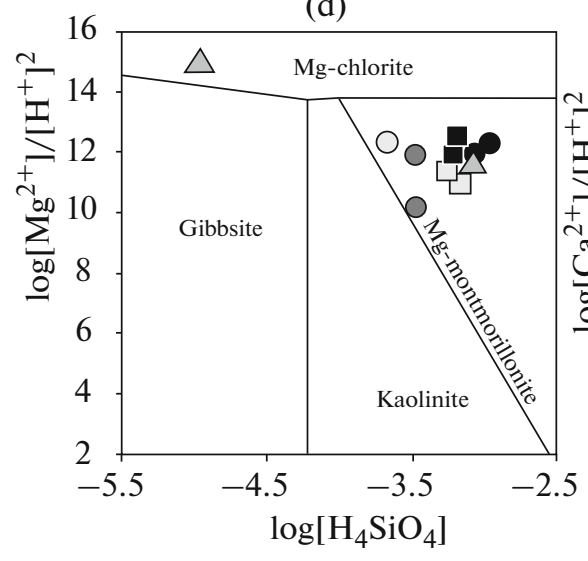

(b)

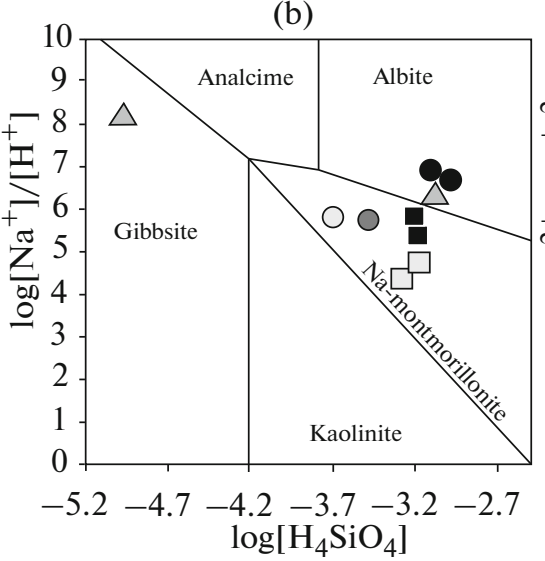

(e)

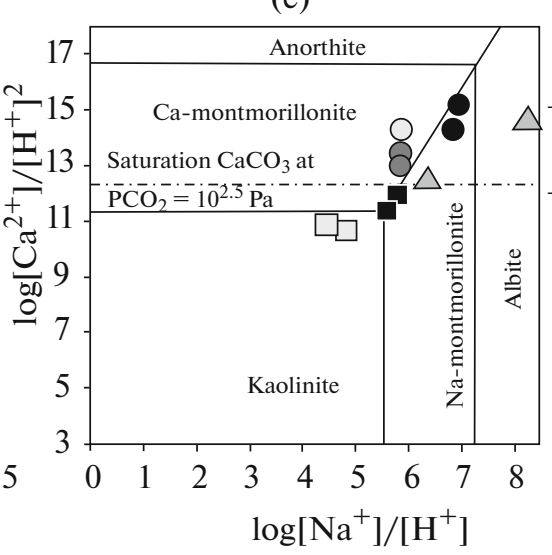

(c)

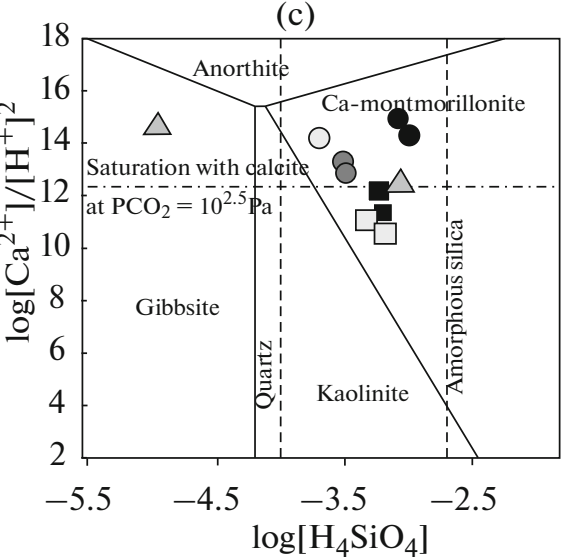

(f)

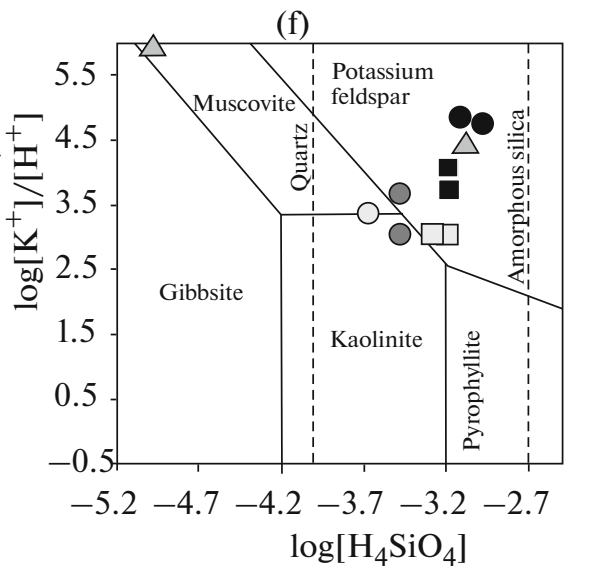

$\square 1 \bullet 2 \triangle 3 \bigcirc 4 \circ 5 \bullet 6$

Fig. 3. Equilibrium diagrams for ground water and alumosilicate minerals at a temperature of $25^{\circ} \mathrm{C}$. (a) muscovite-illite-Kmontmorillonite-kaolinite-gibbsite; (b) analcite-albite-Na-montmorillonite-kaolinite-gibbsite; (c) anorthite-Ca-montmorillonite-kaolinite-gibbsite; (d) Mg-chlorite-chlorite-Mg-montmorillonite-kaolinite-gibbsite; (e) anorthite-albite-Camontmorillonite-Na-montmorillonite-kaolinite; (f) muscovite-PFS-pyrophyllite-kaolinite-gibbsite. PFS stands for potassium feldspar. For legend see Fig. 2.

minerals and the value of SI increases as the water is being saturated with secondary minerals, unlike the A index that was used previously by Kopylova et al. (2014); this is more easily grasped in interpretations of results of hydrogeochemical observations.

The materials of the 1989-1999 continuous observations conducted by the KB GS PAS were used to find time-dependent changes of the SI parameters with respect to secondary alumosilicate minerals, calcite, anhydrite, etc. in relation to past earthquakes of a magnitude of approximately 7 or greater that were accompanied by shakings of intensity V-VI on the MSK-64 scale in areas of the observing stations (Figs. 5 through 7, Fig. 1).

\section{A Description of the Area and the Hydrogeochemical Effects due to Earthquakes}

The geological and tectonic setting of the area is controlled by its location in the zone of contact between the Pacific oceanic plate and the Eurasian continental plate. The boundary between the two plates passes in the area of the Kuril-Kamchatka deepsea trench (see Fig. 1). The oceanic plate is subducted northwest in this location under Kamchatka down to depths of $600 \mathrm{~km}$. The top of the subducted plate and the overlying features of the continental plate are marked by clusters of earthquake hypocenters with maximum magnitudes reaching 8-9; this seismicity volume marks the Kamchatka segment of the KurilKamchatka seismic dipping (Benioff) zone (Fedotov et al., 1985).

The Petropavlovsk Geodynamic Test Site is situated in the middle of the Kamchatka segment of the Kuril-Kamchatka island arc; it lies at the intersection between the Malki-Petropavlovsk folded block zone of transverse faults and the superimposed East Kamchatka and South Kamchatka volcanic belts (Geologiya ..., 1964]. The area shows intensive tectonic activity and high heat and mass transfer within the crust and upper mantle accompanied by occurrences of present-day volcanism and hydrothermal activity. The area of 


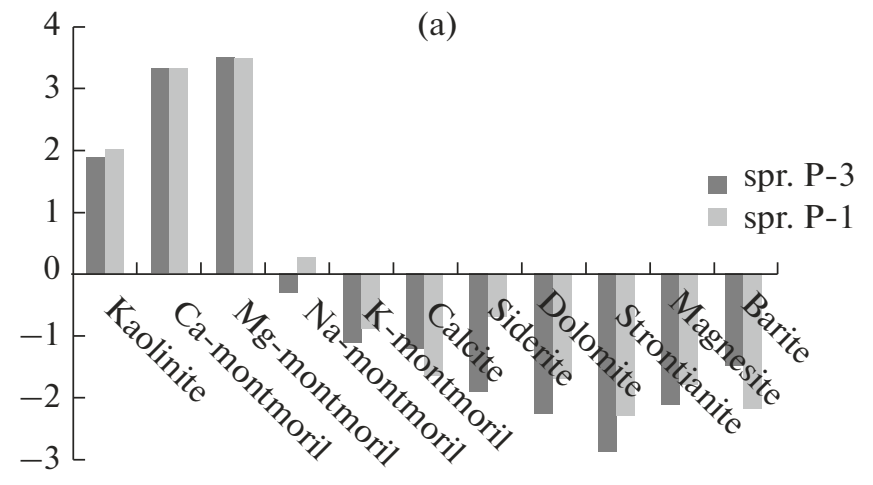

(d)
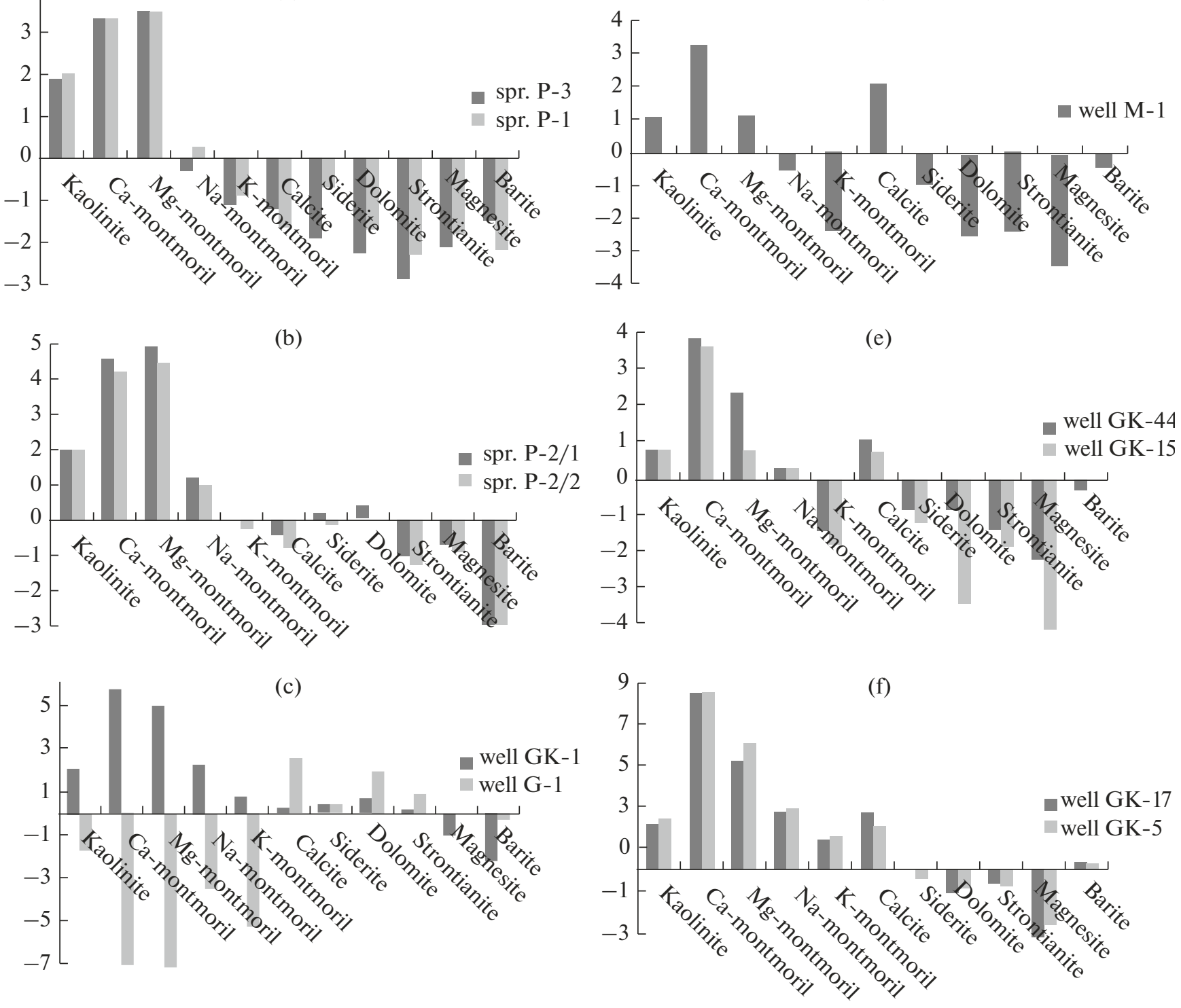

Fig. 4. Saturation parameters for ground water with different types of alumosilicate, carbonate, and sulfate minerals. (a) fresh subthermal pore-fissure hydrocarbonate-chloride waters from springs P-3 and P-1 at Pinachevo; (b) fresh subthermal fissure hydrocarbonate-chloride waters from springs P-2/1 and P-2/2, Pinachevo; (c)saline subthermal fissure and fissure-vein chloride waters from well GK-1, Pinachevo and well G-1, Khlebozavod; (d) ultrafresh subthermal fissure-vein sulfate waters from M-1 well, Moroznaya station; (e) fresh sulfate subthermal fissure-vein sulfate waters from wells GK-44 and GK-15, Verkhnyaya Paratunka station; (f) brackish thermal sulfate fissure-vein waters from wells GK-17 and GK-5, Verkhnyaya Paratunka station.

study contains active volcanoes: Avachinsky, Koryaksky, Mutnovsky, Gorelyi and thermal occurrences in the Paratunka, Pinachevo, and Ketkinskaya hydrothermal systems (Gidrogeologiya ..., 1972).

The water resources in the area are largely replenished by infiltration of thaw water from glaciers and by atmospheric precipitation (Kiryukhin et al., 2015). The local geology pertinent to the circulation of ground water divides the area into three hydrodynamic zones (Manukhin, 1971): (1) an upper zone of free cold water exchange in unconsolidated Quaternary sediments and in rocks that make up a regional zone of exogenous cracking in Late Cretaceous to Neogene, igneous and compacted volcanogenic-sedimentary rocks; (2) a zone of impeded water exchange within subsided areas in the Avachinsky volcano-tectonic depression and structural depressions in the Petropavlovsk horst, which are composed of compacted and poorly metamorphosed volcanogenic-sedimentary and terrigenous rocks dating back to Late Cretaceous and Neogene time; and (3) a zone of active thermal water exchange within the Paratunka, Pinachevo, and Ketkinskaya hydrothermal systems. 


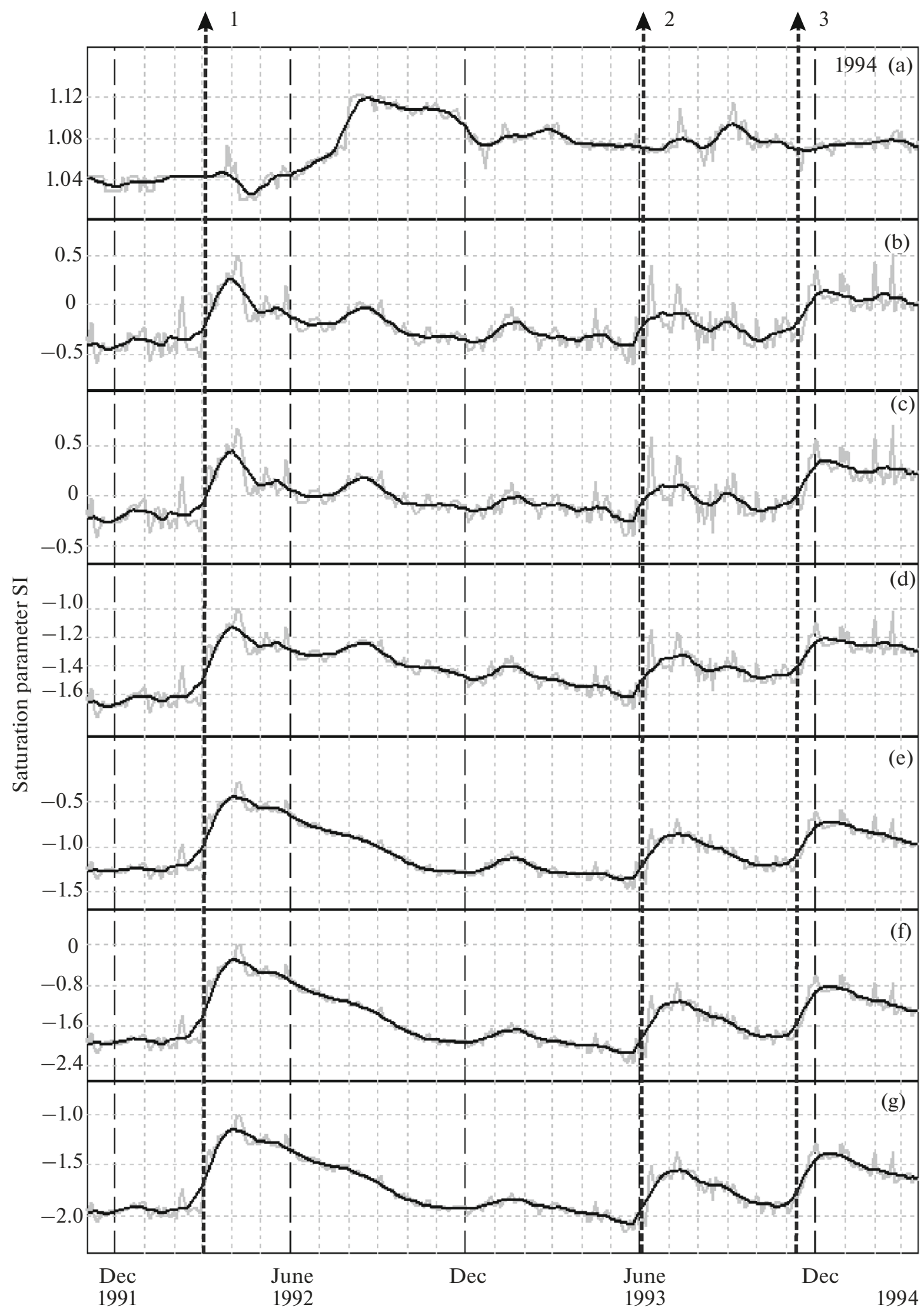

Fig. 5. The variation in the saturation of ground water from spring P-1, Pinachevo station with kaolinite (a), Ca-montmorillonite (b), Mg-montmorillonite (c), Na-montmorillonite (d), calcite (e), dolomite (f), and magnesite (g) in 1991-1994. Heavy lines show averaged saturation indices in a moving time window of 30 days at a step of 3 days. The vertical arrows marks the time of earthquakes: 1 -March 2, 1993, $M=6.8$; 2-June 8, 1993, $M=7.5$; 3-November 13, 1993, $M=7.0$. 


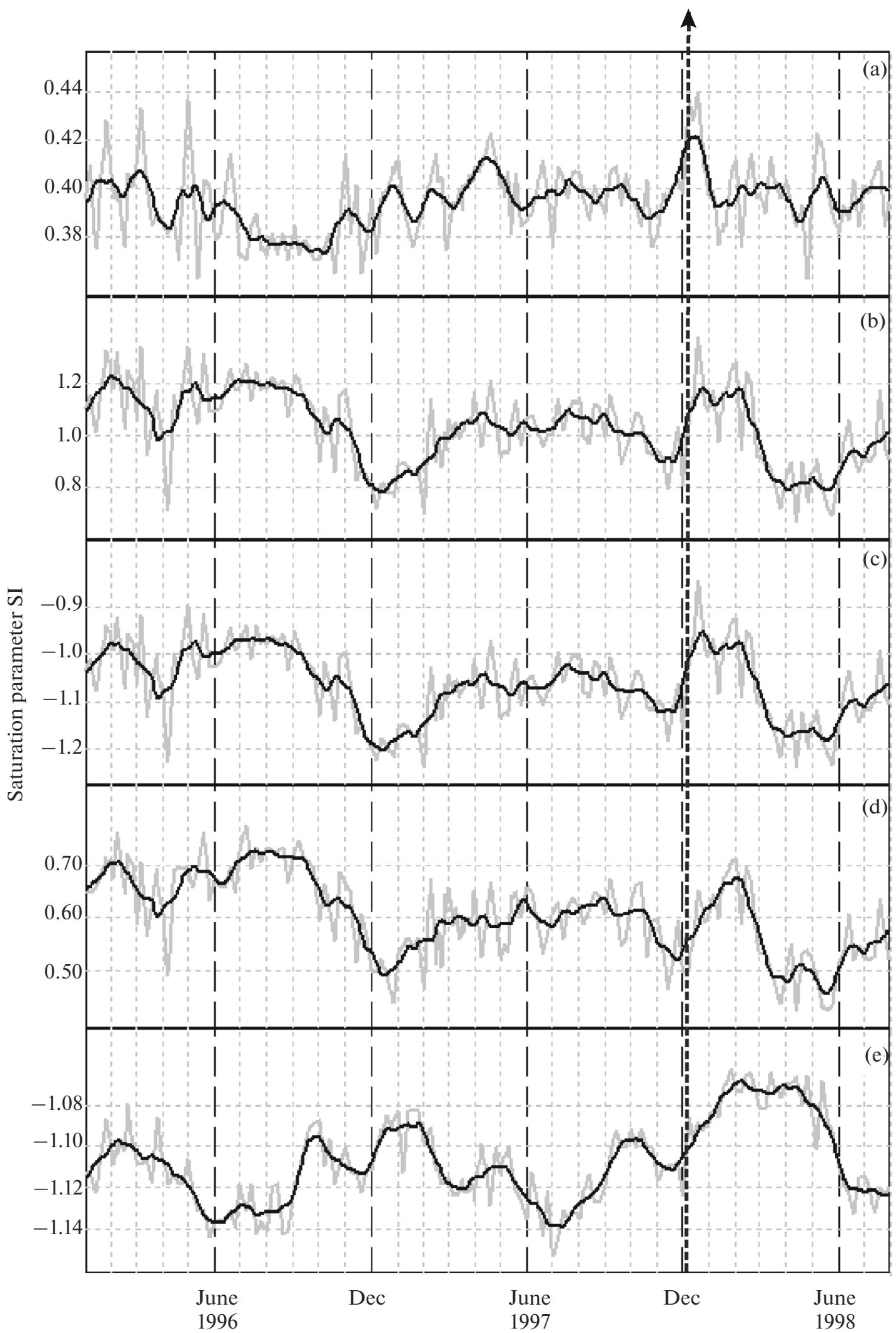

Fig. 6. The 1996-1998 variation in the saturation of ground water from well GK-15, Verkhnyaya Paratunka station with respect to kaolinite (a), Ca-montmorillonite (b), Na-montmorillonite (c), calcite (d), and anhydrite (e). Heavy lines show averaged theoretical saturation indices in a moving time window of 30 days at a step of 3 days. The vertical arrow marks the time of the $M=7.8$, December 5, 1997 earthquake. 


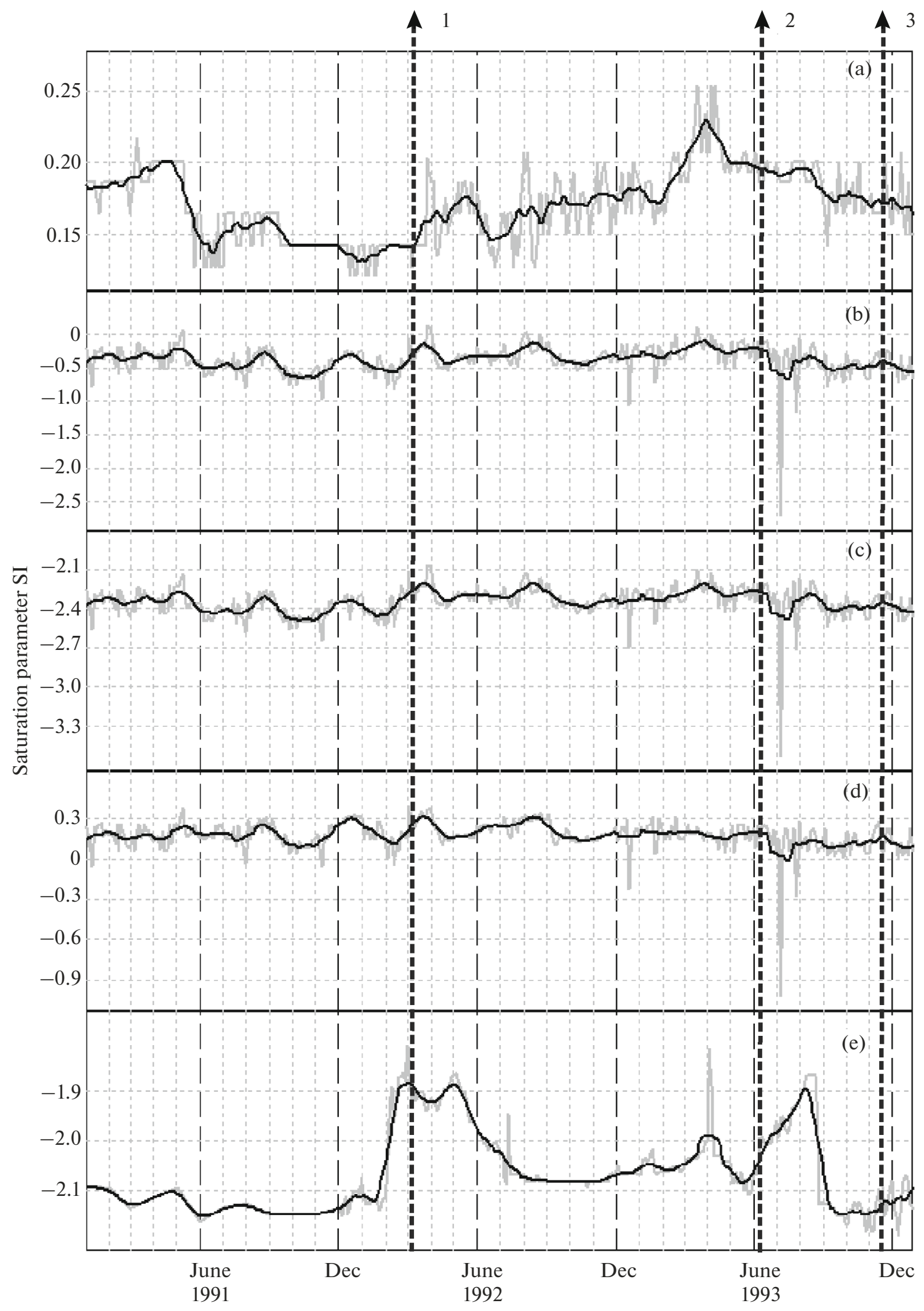

Fig. 7. The 1991-1993 variation in the saturation of ground water from M-1 well with respect to kaolinite (a), Ca-montmorillonite (b), Na-montmorillonite (c), calcite (d), and anhydrite (e). Heavy lines show averaged theoretical saturation indices in a moving time window of 30 days at a step of 3 days. The vertical arrows mark the times of earthquakes: $1-$ March 2, 1993, $M=6.8 ; 2-$ June 8, 1993, $M=7.5 ; 3-$ November 13, 1993, $M=7.0$. 
Seismicity. The largest seismic events near the Petropavlovsk Test Site were four earthquakes during the time of observation (see Fig. 1) that caused intensity $I=\mathrm{V}-\mathrm{VI}$ shaking on the MSK-64 scale in the areas of observing stations. The shaking due to these earthquakes caused anomalies in the variation of macrocomponent concentrations in water and gas sampled from the Pinachevo, Moroznaya, Verkhnyaya Paratunka, and Khlebozavod stations (postseismic effects). The GK-1, M-1, and G-1 wells showed anomalies in the variation of macrocomponent concentrations in water prior to earthquakes (hydrogeochemical precursors).

Below, we present a brief description of the stations incorporating the 2014 survey results and the previously detected hydrogeochemical effects of large earthquakes after (Kopylova et al., 1994; Khatkevich and Ryabinin, 2004).

The Pinachevo station is situated near the base of the Pinachevo extrusive dacitic andesite massif and contains a flowing well (GK-1) $1261 \mathrm{~m}$ deep and four springs ( $\mathrm{P}-1, \mathrm{P}-2 / 1, \mathrm{P}-2 / 2$, and $\mathrm{P}-3)$. The permanent water discharges are in the zone where there are discharges of nitrogen-methane chloride calciumsodium thermal waters in the Pinachevo hydrothermal system. These waters are abundant in the dacitic andesites of the extrusive massif and in volcanogenic, volcanogenic-sedimentary, and sedimentary deposits dating from Quaternary, Late Paleogene to Neogene, and Late Cretaceous time in the Avachinsky volcanotectonic depression. Structurally speaking, the discharge of springs and the localization of numerous anomalies in the chemical composition of ground water and surface waters are controlled by the northwest trending deep-seated Petropavlovsk fault and the zones of high cracking that are feather features with respect to that fault (Polyak et al., 1965; Kopylova, 1992).

The GK-1 well was drilled approximately $100 \mathrm{~m}$ from the springs; it reached a chloride calciumsodium headwater with a mineral content of $11.1 \mathrm{~g} / \mathrm{L}$ in the depth range 400-1260 m. Its discharge rate is $0.1 \mathrm{~L} / \mathrm{s}$. The free gas from well GK-1 has a nitrogenmethane composition $\left(\mathrm{CH}_{4}\right.$ at $80 \mathrm{vol} \%$ and $\mathrm{N}_{2}$ at 20 vol \%).

The chemical composition of the water in springs varies between hydrocarbonate calcium-magnesium and hydrocarbonate-chloride sodium and is determined by different degrees of dilution in the upgoing flow of chloride calcium-sodium thermal waters with fresh cold waters that are abundant in unconsolidated Quaternary deposits and in the dacitic andesite zone of weathering. The mineral content in the spring water is $0.1-1.0 \mathrm{~g} / \mathrm{L}$, the temperature is $6-11^{\circ} \mathrm{C}$, and the discharge rates are $0.1-0.4 \mathrm{~L} / \mathrm{s}$. The free gas is dominated by nitrogen $\left(\mathrm{N}_{2} \geq 75 \mathrm{vol} \%\right.$ and $\left.\mathrm{CH}_{4} \leq 25 \mathrm{vol} \%\right)$.

Large earthquakes (see Fig. 1) were accompanied by variations in the chemical composition of water sampled from well GK-1 that were recognized as hydrogeochemical precursors in the form of lower concentrations of macrocomponents $\left(\mathrm{Cl}^{-}, \mathrm{Na}^{+}\right.$, and $\mathrm{Ca}^{2+}$ ), giving way to higher concentrations after the earthquakes (the postseismic effect). The precursors and the postseismic effects lasted for a few months. The variations in the chemical composition of spring water showed a postseismic increase in the concentrations of $\mathrm{Cl}^{-}, \mathrm{HCO}_{3}^{-}, \mathrm{Na}^{+}, \mathrm{Ca}^{2+}, \mathrm{Mg}^{2+}$, etc.

The Khlebozavod station. Flowing well G-1 reached nitrogen-methane chloride sodium waters with a mineral content of $12.6 \mathrm{~g} / \mathrm{L}$ at depths of 1710 $2424 \mathrm{~m}$, which are abundant in Late Cretaceous bituminized sedimentary deposits that make up a local depression within the Petropavlovsk horst. The discharge rate of the well is below $0.01 \mathrm{~L} / \mathrm{s}$. The water sampled from well G-1 before and after the M 7.8 December 5, 1997 earthquake showed a change in the concentrations of macrocomponents $\left(\mathrm{Cl}^{-}\right.$and $\left.\mathrm{Na}^{+}\right)$ (Khatkevich and Ryabinin, 2004).

The Moroznaya station. Well M-1 was drilled within the Nachiki zone of folded block dislocations. The well tapped sodium-calcium sulfate headwater at depths of 310-556 m with a mineral content of $0.14 \mathrm{~g} / \mathrm{L}$ and a temperature of $16^{\circ}$. The water is contained in Late Neogene volcanogenic-sedimentary deposits. The discharge rate of the well is $1.5 \mathrm{~L} / \mathrm{s}$. Judging from the combined hydrodynamic and hydrogeochemical features (seasonal changes in discharge rate and temperature and low mineral content), the water sampled from the well is in a hydrodynamic zone of free water exchange.

Well M-1 showed a hydrogeochemical precursor before earthquakes (see Fig. 1) in the form of higher concentrations of $\mathrm{SO}_{4}^{2-}, \mathrm{Na}^{+}$, and $\mathrm{Ca}^{2+}$ ions with a simultaneous decrease in the concentration of $\mathrm{HCO}_{3}^{-}$. This was accompanied by an increase of $20 \%$ in the mineral content (Kopylova et al., 1994; Kopylova and Boldina, 2012).

The Verkhnyaya Paratunka station. Wells GK-5, GK-15, GK-17, and GK-44 discharge thermal nitrogen waters from depths of $125-1200 \mathrm{~m}$ within the structural depressions of the Paratunka and Karymshina rivers. All of the four wells are not allowed free access to the surface; most of the time they are closed with screw caps. When sampling is needed, the caps are opened. The waters are chloride-sulfate and sulfate sodium in composition with $M=0.4-1.5 \mathrm{~g} / \mathrm{L}$ (Kopylova et al., 1994; Khatkevich and Ryabinin, 2004).

The ground water in all observing wells is of a headwater type coming from different depths: 400-1260 m in well GK-1; 310-556 $\mathrm{m}$ in the M-1 well; $1710-2424 \mathrm{~m}$ in well G-1, and 125-1200 $\mathrm{m}$ in wells GK-5, GK-15, GK-17, and GK-44. These typically show fissured and fissure-vein types of circulation in compacted poorly metamorphosed volcanogenic-sedimentary and Late Cretaceous to Neogene terrigenous deposits. The 
waters in the Pinachevo springs are nonartesian in type (P-3 and $\mathrm{P}-1)$ and are at low pressures $(\mathrm{P}-2 / 1$ and $\mathrm{P}-2 / 2)$; they are typically pore-fissured and fissured types of circulation in the deposits of the weathering zone of the extrusive massif of dacitic andesites and unconsolidated mantle deposits dating from the Quaternary. The chemical composition of water discharged at the Pinachevo, Moroznaya, and Khlebozavod stations is formed under natural conditions without the influence of human-induced factors and intraannual seasonal variation in water recharge. The variation in the water composition as sampled from the Verkhnyaya Paratunka wells is little affected by withdrawal from the Paratunka thermal field because the wells are far from the water intake areas.

\section{RESULTS \\ The Conditions of Formation and Chemical Composition in the Water Discharges}

The chemical composition of the ground water in wells and springs varies (see Tables 1 and 2, Fig. 2). This is controlled by a complex combination of natural factors that affect the processes of their origination in eastern Kamchatka (Gidrogeologiya ..., 1972). The observed features in the composition such as the mineral content, prevailing anions and cations, gases, and the concentrations of microcomponents, are largely controlled by their occurrence in different waterexchange zones. Important contributions are also due to the local geology and tectonics, such as the composition of the host rocks and the character of the hydrogeologic feature concerned, as well as the degree of its closeness/openness and of hydrodynamic connections to ground water in shallow and deeper zones. These factors, as well as the past evolution of the station areas with their specific features in the evolution of the ground-water composition, all combine to determine the present-day chemical composition of waters in permanent water discharges, as affected by incoming mineral components from water-bearing rocks, from adjacent aquifers, and from highly cracked zones.

The degree of hydrodynamic connections to "deep-seated" hydrothermal waters also affects the chemical composition of water sampled in wells and springs that are situated in the discharge zones of present-day hydrothermal systems (the Pinachevo system with the Pinachevo station and the Paratunka system with the Verkhnyaya Paratunka station). The composition of hydrothermal water in comparatively isolated fragments of hydrothermal systems controls the hydrogeochemical background of ground waters in their discharge areas owing to mixing between brackish and saline waters from zones of impeded water exchange on the one hand and fresh water from zones of free water exchange on the other. The "deepseated" waters in the Pinachevo area are chloride nitrogen-methane, calcium-sodium saline waters that are enriched in a broad range of microcomponents. Their discharge and mixing with the fresh water coming from the upper hydrodynamic zone of free water exchange can explain anomalies of higher concentrations of $\mathrm{Cl}^{-}, \mathrm{Na}^{+}$, silicic acid, methane, helium, and other geochemical indicators in ground waters and shallow waters in the base of the Pinachevo extrusive basin and in the Pinachevo R. basin (Polyak et al., 1965).

Drilling in the warmer parts of the Paratunka hydrothermal system revealed the presence of nitrogen chloride-sulfate and calcium-sodium sulfate brackish waters at temperatures of $100^{\circ} \mathrm{C}$ or greater. The areas of their concentrated discharge and areas of dispersed discharge owing to mixing with waters from overlying horizons of cold fresh water are marked at the ground surface by higher temperatures and concentrations of ions of chlorine, sulfate, sodium, and silicic acid, as found in the composition of shallow and ground waters (Manukhin and Vorozheikina, 1976).

The ground waters under study contain the following types of water as identified by its hydrogeological features, temperature, and chemical composition: (1) nonartesian (subsoil), pore-fissure, fresh cold waters in the upper hydrodynamic zone of free water exchange (springs P-3 and P-1 at the Pinachevo station); (2) low-pressure pore-fissure and fissure fresh subthermal waters in the upper hydrodynamic zone of free water exchange (springs $\mathrm{P}-2 / 1$ and $\mathrm{P}-2 / 2$ at the Pinachevo station); (3) fissure and fissure-vein saline subthermal headwaters in the hydrodynamic zone of difficult water exchange (well GK-1 at Pinachevo and well G-1 at Khlebozavod station); (4) fissure-vein ultrafresh subthermal headwaters in the hydrodynamic zone of free water exchange (the $M-1$ well at the Moroznaya station); (5) fissure-vein fresh subthermal headwaters in the active water exchange zone within the Paratunka hydrothermal system (wells GK-44 and GK-15 at the Verkhnyaya Paratunka station); and (6) fissure-vein brackish thermal headwaters in the active water exchange zone within the Paratunka hydrothermal system (wells GK-17 and GK-5 at Verkhnyaya Paratunka).

The upper zone of free cold-water exchange in the Pinachevo station area contains fresh, mostly fissure waters in a zone of exogenous fissuring in dacitic andesites and pore waters in unconsolidated mantle deposits. Springs P-3 and P-1 discharge cold, ultrafresh and fresh hydrocarbonate-chloride magnesium-calcium and sodium waters with mineral concentrations of 126 and $409 \mathrm{mg} / \mathrm{L}$ and at temperatures of $6.2^{\circ} \mathrm{C}(\mathrm{P}-3)$ and $7.6^{\circ} \mathrm{C}(\mathrm{P}-1)$. The concentration of silicon in these waters is $15-16 \mathrm{mg} / \mathrm{L}$, in addition to the presence of sulfate ion up to $4.8 \mathrm{mg} / \mathrm{L}$. Springs $\mathrm{P}-2 / 1$ and $\mathrm{P}-2 / 2$ discharge fissure waters at temperatures of $10.3-11.1^{\circ} \mathrm{C}$ and a mineral content of $934-955 \mathrm{mg} / \mathrm{L}$; these waters are low-alkali with $\mathrm{pH} 7.8-7.9$, their composition is hydrocarbonate-chloride sodium with 
16-17\%-eq. of magnesium and the concentration of silicon up to $17 \mathrm{mg} / \mathrm{L}$ without sulfate ions.

The spring water is characterized by low-alkali conditions of the geochemical environment with Eh between $75 \mathrm{mV}(\mathrm{P}-1)$ and $-2 \ldots-3 \mathrm{mV}(\mathrm{P}-2 / 1, \mathrm{P}-2 / 2)$, showing the different contributions of hydrothermal waters that are formed under reducing conditions into their water discharge.

Fissure-vein, low-alkali ( $\mathrm{pH}$ 8.9), ultrafresh $(M=$ $0.13 \mathrm{~g} / \mathrm{L}$ ) water from the $\mathrm{M}-1$ well at the Moroznaya station whose temperature is $15.7^{\circ} \mathrm{C}$ and whose composition is sulfate sodium-calcium with a silicon concentration of $5.8 \mathrm{mg} / \mathrm{L}$ is also formed in the upper hydrodynamic zone of free cold water exchange. It typically exhibits oxidizing conditions of the geochemical environment with Eh $85 \mathrm{mV}$.

Subthermal saline fissure-vein waters in well GK-1 at Pinachevo and well G-1 at Khlebozavod are formed in zones of relatively difficult water exchange within subsided areas of structural depressions. Well GK-1 discharges saline water with a mineral content of $11.1 \mathrm{~g} / \mathrm{L}$ under low reducing conditions of the geochemical environment with Eh $88 \mathrm{mV}, \mathrm{pH} 7.5$, and the presence of ammonium ions (up to $2.4 \mathrm{mg} / \mathrm{L}$ ); the composition is chloride calcium-sodium, with a silicon concentration occasionally reaching $22.7 \mathrm{mg} / \mathrm{L}$ and higher concentrations of potassium, lithium, and boron $(16.3 \mathrm{mg} / \mathrm{L})$. The presence of high concentrations of barium $(11.7 \mathrm{mg} / \mathrm{L})$ and strontium $(79.1 \mathrm{mg} / \mathrm{L})(\mathrm{see}$ Table 2) indicates possible secondary mineral generation of sulfates and carbonates in the ground water of the Pinachevo station area. Higher temperatures of the water (reaching $60^{\circ} \mathrm{C}$ at a depth of $1200 \mathrm{~m}$ ) and high concentrations of silicon, boron, and several microcomponents provide evidence of a substantial contribution from a deeper thermal component in the GK-1 water.

Well G-1 at the Khlebozavod station discharges saline chloride sodium water with a mineral content of $12.6 \mathrm{~g} / \mathrm{L}$ under low-reducing conditions with Eh-16 $\mathrm{mV}$; the water temperature is $14.3^{\circ} \mathrm{C}, \mathrm{pH} 9.9$, with the concentration of ammonium ions equal to $8.9 \mathrm{mg} / \mathrm{L}$, $3.8 \mathrm{mg} / \mathrm{L}$ as the concentration of fluorine and $48 \mathrm{mg} / \mathrm{L}$ for potassium, and no silicon. The microcomponent composition includes higher concentrations of lithium $(3.2 \mathrm{mg} / \mathrm{L})$, boron $(21.4 \mathrm{mg} / \mathrm{L})$, vanadium, gallium, germanium, rubidium, strontium $(25.3 \mathrm{mg} / \mathrm{L})$, antimony, bromine, barium, rare-earth elements, thallium, and lead (see Table 2).

The fissure-vein subthermal waters from wells GK-44 and GK-15 and the thermal waters from wells -GK-17 and GK-5 at the Verkhnyaya Paratunka station are formed in the zone of active thermal water exchange (Manukhin, 1971). The subthermal fissurevein waters from well GK-44 at a temperature of $T=$ $20^{\circ} \mathrm{C}$ and those from well GK-15 $\left(T=25.5^{\circ} \mathrm{C}\right)$ are fresh waters with mineral concentrations of $0.41 \mathrm{~g} / \mathrm{L}$ and $0.77 \mathrm{~g} / \mathrm{L}$, respectively. These are low-alkali waters with $\mathrm{pH} 8$; their composition is sulfate calciumsodium with the presence of chlorine $15-19 \%$-eq., with a silicon concentrations of 9.0 and $9.6 \mathrm{mg} / \mathrm{L}$, the presence of fluorine $(0.5-1.6 \mathrm{mg} / \mathrm{L})$, lithium $(0.26-$ $0.37 \mathrm{mg} / \mathrm{L}$ ), boron, gallium, arsenic, molybdenum, antimony, tungsten, and lead.

Wells GK-17 and GK-5 discharge thermal fissurevein waters at temperatures of $37.4^{\circ} \mathrm{C}$ and $75.5^{\circ} \mathrm{C}$. These are alkaline ( $\mathrm{pH} 8.8-8.9)$. Their mineral content is $0.98 \mathrm{~g} / \mathrm{L}$ and $1.47 \mathrm{~g} / \mathrm{L}$. Their composition is chloride-sulfate sodium and sulfate calcium-sodium with $16 \%$-eq. chlorine and silicon concentrations of 20.7 and $25.6 \mathrm{mg} / \mathrm{L}$.

The fissure-vein thermal waters at the Verkhnyaya Paratunka station contain higher concentrations of fluorine (between 3.75 and $3.02 \mathrm{mg} / \mathrm{L}$ ), lithium (between 0.66 and $0.87 \mathrm{mg} / \mathrm{L}$ ), boron (up to $5 \mathrm{mg} / \mathrm{L}$ ), gallium, germanium, arsenic, rubidium, molybdenum, zirconium, antimony, cesium, tungsten, and lead. The distinguishing features of these waters also include alkaline properties of the geochemical environment and increasing concentrations of sulfate and chlorine ions as the water temperature and depth of the wells increase.

Classification of ground water. Chemical compositional diagrams based on water discharges sampled (see Fig. 2) revealed three sets of ground water: set I includes fresh hydrocarbonate-chloride magnesiumsodium and sodium waters in the zone of free water exchange in the Pinachevo extrusive massif; set II includes saline chloride calcium-sodium and sodium waters in zones of relatively difficult water exchange in subsided parts of structural depressions; set III includes sulfate sodium-calcium cold ultrafresh and sulfate calcium-sodium fresh and brackish thermal waters within the Nachiki zone of folded block dislocations.

One characteristic parameter to use to judge the composition of saline waters from wells GK-1 and G-1 (set II) in the zone of difficult water exchange in subsided parts of depressions is the presence of ammonium ions as indicating a reducing environment (see Table 1). The accumulation of the main macrocomponents (sodium and chlorine) in such waters is accompanied by increasing concentrations of lithium, fluorine, boron, and bromine. At the same time, one can see a differentiation of cations depending on the composition of the host rocks. As an example, the ground water from well G-1 in Late Cretaceous rocks is a chloride sodium type with the presence of sulfate ions and increased concentrations of boron, lithium, fluorine, and bromine, and the absence of silicon and iron. The $\mathrm{Cl} / \mathrm{Na}$ ratio for this water is close to unity, suggesting the influence of marine brines on the formation of its chemical composition. The saline waters from well GK-1, which are also formed in Upper Cretaceous deposits, typically exhibit an absence of sulfate ions and a chloride calcium-sodium composition 
with the presence of bromine, boron, lithium, and iron (up to $2.71 \mathrm{mg} / \mathrm{L}$ ) and silicon (19.9 mg/L). These features in the composition of the GK-1 water can be due to the activity of sulfate-reducing bacteria and to reduction of sulfur under reducing conditions in the presence of organic matter (Gidrologiya ..., 1972).

The chemical composition of all the three sets of water is also controlled by how the water interacts with minerals in the host rocks and by stages of secondary mineral generation (Shvartsev, 1998, 2008; Shvartsev et al., 2007), which can be monitored from the equilibrium state of waters with alumosilicate minerals (see Fig. 3) and from the degree of saturation with alumosilicate, carbonate, and sulfate minerals (Table 3, see Fig. 4).

An analysis of the diagrams in Fig. 3 shows that the interaction between the ground waters of interest and rocks is equilibrium-disequilibrium in character (Shvartsev, 2008). The locations of the theoretical points shows that the ground waters of permanent water discharges are under varying degrees of saturation with secondary alumosilicate and chemogenic minerals (calcite, siderite, dolomite, and barite), and they are generally not saturated with endogenous minerals and anhydrite.

The ground waters from springs $\mathrm{P}-1$ and $\mathrm{P}-3$ are formed in the zone of free water exchange; they are at the initial phases of evolution of the water-rock system during their interaction with alumosilicate rocks. They are saturated with kaolinite, $\mathrm{Ca}$ - and $\mathrm{Mg}$-montmorillonites, and are in equilibrium with Na-montmorillonite. Fresh fissure waters from springs P-2/1 and $\mathrm{P}-2 / 2$ are saturated with $\mathrm{Ca}-, \mathrm{Mg}_{-}$, and $\mathrm{Na}-$ montmorillonites, and reach equilibrium with $\mathrm{K}$ montmorillonite. In addition, they are in equilibrium with chemogenic minerals (siderite and dolomite).

The diagrams of stability fields for alumosilicate minerals (see Fig. 3) exhibit a directivity in the compositional evolution of chloride waters in set II and sulfate waters in set III, going from an equilibrium of these waters with kaolinite to an equilibrium with montmorillonites and primary minerals. The stability field of albite and potassium feldspar contains points relevant to thermal sulfate water and saline chloride water.

The data on the chemical composition of water and thermodynamic calculations show that the waters from permanent wells and springs are at different stages of interaction in the water-rock system and are saturated with kaolinite, $\mathrm{Ca}-, \mathrm{Mg}-$, $\mathrm{Na}$-, and $\mathrm{K}$-montmorillonites, calcite, and barite and that these waters are in an approximate equilibrium with siderite. As well, one can hypothesize for these waters that the evolution of the interaction in the water-rock system will be accompanied by an increasingly more complicated range of secondary newly formed minerals, and they will reach equilibrium with chemogenic minerals (calcite, siderite, dolomite, and barite). As well, as the time of interaction in the water-rock system is increasing from set I waters, which have the shortest times of this interaction, to waters of sets II and III, the parameters that characterize saturation with newly formed minerals would increase, which is especially characteristic for ground waters in the hydrodynamic zone of difficult water exchange from wells GK-1 and G-1 (see Fig. 4).

\section{Variations in the Saturation of Ground Water with Secondary Minerals in Relation to Large Earthquakes}

Figures 5 through 7 show examples where the variation in the saturation with secondary minerals (SI) is reconstructed for waters in set I (spring P-1) and in set III (wells GK-15 and M-1) in relation to past large earthquakes (see Fig. 1). These plots of the variation in SI values over time are mere estimates (qualitative determinations), because the calculations were based on thermodynamic parameters for reactions where water was interacting with minerals at an assumed temperature of $25^{\circ} \mathrm{C}$ (Garrels and Christ, 1965). This approach to the analysis of variation for saturation indices in comparison with earthquakes highlights the amplitudes and the overall character of variation of SI values.

The variation of SI indices for the waters of spring P-1 and well GK-15 exhibits an increase for several months after earthquakes that occurred at epicentral distances of $120-300 \mathrm{~km}$ from the stations and produced shaking of intensity V-VI on the MSK scale (the postseismic effect). When maxima were reached, the SI values began to decrease gradually and then to stabilize.

The changes in the saturation of ground water with secondary minerals were hardly noticeable in the water of spring P-1, well GK-15 and other water discharges during the precursory periods before earthquakes. One exception is the M-1 well, where the water was found to show an appreciable increase in the SI index toward anhydrite during the month before the March 2, 1992 earthquake (see Fig. 7). The effect of increasing anhydrite saturation in the M-1 water was previously identified as a new type of hydrogeochemical precursor that was due to changes in interaction in the water-rock system (Kopylova et al., 2014). As well, a sudden short-lived increase in the saturation of the M-1 ground water toward anhydrite was observed 2 months before the earthquake of June 8, 1993 (see Fig. 7). Higher SI values tending toward anhydrite were also recorded during 2 months after the earthquakes of March 2, 1992 and June 8, 1993 (the postseismic effect).

\section{DISCUSSION OF RESULTS}

This study is the first special hydrogeochemical sampling of ground water at eleven permanent water discharges in the Petropavlovsk Test Site in order to 
THE CHEMICAL COMPOSITION

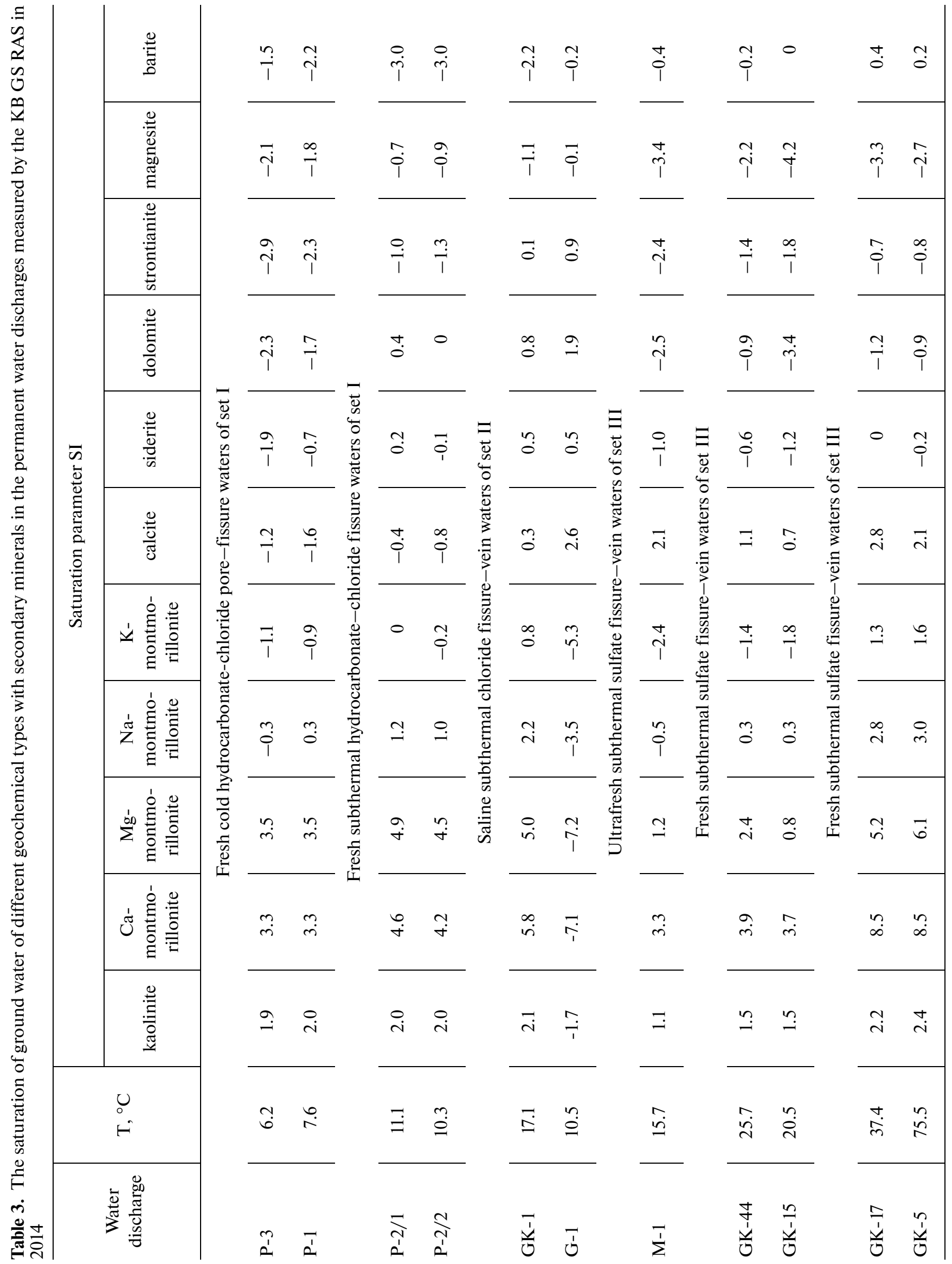


investigate how the water composition is formed in the water-rock system; a classification is proposed for ground water based on chemical compositions that incorporate the physical and chemical properties of waters and their occurrence in different hydrodynamic zones of water exchange and under different local geological conditions. Three sets of ground waters have been identified: set I includes pore-fissure and fissure ground waters in the zone of active fresh cold water exchange of mostly hydrocarbonate-chloride compositions, set II includes saline fissure and fissure-vein subthermal waters in the zone of difficult water exchange of predominantly chloride compositions, set III includes cold and thermal fresh and brackish, fissure-vein waters of prevailing sulfate compositions in the zones of free and active water exchange.

Thermodynamic calculations showed that the waters from wells and springs are at different stages of interaction in the water-rock system (Shvartsev et al., 2007). The ultrafresh cold waters in set I from springs $\mathrm{P} 1$ and $\mathrm{P} 3$ are in equilibrium with kaolinite and with $\mathrm{Ca}-$ and $\mathrm{Mg}$-montmorillonites, i.e., at the stage when the silicic geochemical type of the calcium and magnesium subtypes are formed, according to (Shvartsev et al., 2007). The fresh subthermal waters from springs $\mathrm{P}-1 / 2$ and $\mathrm{P}-2 / 2$ reach equilibrium with Na-montmorillonite (siliceous sodium subtype), calcite, and siderite as well, which shows that the siliceous carbonatecalcium geochemical type of water proper is being formed.

The increased mineral content in water, concentrations of silicon, chlorine, sodium, potassium, as well as several microcomponents in the waters of the upper hydrodynamic zone of free water exchange is due to increased time of interaction in the water-rock system and increased depth of ground-water penetration. The factors due to the time and depth of ground water filtration are responsible for increasing amounts of minerals that are in equilibrium with water, as well as for increasing temperature and decreasing oxidizingreducing potential, which characterizes a less oxidizing geochemical environment.

Taking the example of saline water from well GK-1, which is formed under the conditions of difficult water exchange (set II), we investigated the ability of this water to accumulate several chemical elements owing to increased time of interaction in the water-rock system under reducing conditions of the geochemical environment. This water achieves equilibrium with K-montmorillonite (the siliceous potassium subtype), calcite, siderite, and dolomite, resulting in a siliceous carbonate-calcium geochemical type of water. Under these conditions the ground water has increased con-

centrations of $\mathrm{Si}, \mathrm{Cl}, \mathrm{Br}, \mathrm{B}, \mathrm{NH}_{4}^{+}, \mathrm{Li}, \mathrm{B}, \mathrm{Si}, \mathrm{Na}, \mathrm{Ca}$, and $\mathrm{K}$, as well as of $\mathrm{Mn}, \mathrm{Fe}, \mathrm{Ge}, \mathrm{As}, \mathrm{Br}, \mathrm{Rb}, \mathrm{Sr}$, and $\mathrm{Ba}$ (see Tables 1 and 2).

The saline waters in well G-1 were formed under the conditions of a long-term interaction between ground water and poorly metamorphosed, mostly marine deposits (phyllite-like, bituminized shale, and argillites). These waters typically have $\mathrm{Cl} / \mathrm{Na} \approx 1$ and are in equilibrium with carbonate secondary minerals (calcite, dolomite, and strontianite), as well as in an approximate equilibrium with siderite.

The sulfate waters in the zone of free subthermal water exchange (the M-1 well) and in the zone of active thermal water exchange for waters from the Verkhnyaya Paratunka wells (set III) belong to the siliceous carbonate-calcium (soda) type of water during different stages of its occurrence. The waters successively reach equilibrium with $\mathrm{Ca}-, \mathrm{Mg}_{-}, \mathrm{Na}-$, and $\mathrm{K}$-montmorillonites and calcite. As an example, the ultrafresh water from the M-1 well is observed to be in equilibrium with kaolinite, $\mathrm{Ca}-$ and $\mathrm{Mg}$-montmorillonites, with calcite, and to be consistent with the siliceous magnesium subtype. The fresh thermal water from wells GK-44 and GK-15 also reaches equilibrium with Na-montmorillonite and calcite, which indicates that the siliceous sodium subtype is being formed. As the time of interaction in the system and the temperature are increasing in fresh and brackish thermal waters from wells GK-17 and GK-5, equilibrium is also reached with $\mathrm{K}$-montmorillonite and calcite; the siliceous carbonate-calcium (soda) geochemical type is in formation along with an initial phase of the formation of secondary sulfate minerals (barite).

In the case of set III sulfate waters, one observes an increasing time of interaction between ground water and host rocks, increasing temperature and filtration depth, along with concurrent expansion of the range of clay minerals that are in equilibrium with the water, and the geochemical environment becomes less oxidizing; the concentrations of sulfates, $\mathrm{Na}, \mathrm{Si}, \mathrm{F}, \mathrm{Li}, \mathrm{B}$, as well as of As, Ge, Br, Mo, Sb, Rb, Cs, W, and Th are increasing (see Tables 1 and 2). It can be surmised that as the set III waters acquire greater saturation with secondary minerals more favorable situations are created for identifying hydrogeochemical earthquake precursors.

As the water-rock system progresses, one observes a more complicated range of secondary newly formed minerals and the waters reach equilibrium with chemogenic minerals (calcite, siderite, dolomite, and barite). In addition, as the time of interaction increases in the water-rock system, which is especially characteristic for the waters from wells GK-1, G-1, GK-17, and GK-5, so do the parameters of saturation with newly formed minerals (see Table 3, Fig. 4).

The large earthquakes of 1992-1993 and 1997 were followed by increased saturation of the waters with secondary minerals (see Figs. 5, 6). This indicates a changed interaction in the water-rock systems related to such earthquakes. This postseismic effect was especially pronounced in relation to the earthquake of March 2, 1992. A new type of geochemical precursor was identified before this event, consisting in an increased 
Table 4. The variation in the saturation of ground water in the Verkhnyaya Paratunka wells with sulfate minerals as determined from the 2014 sampling survey

\begin{tabular}{c|c|c|c}
\hline Well & Mineral content, mg/L & $\begin{array}{c}\text { Saturation with barite } \\
\text { (saturation parameter SI) }\end{array}$ & $\begin{array}{c}\text { Saturation with anhydrite } \\
\text { (saturation parameter SI) }\end{array}$ \\
\hline GK-44 & 407 & -0.225 & -1.690 \\
GK-15 & 773 & 0.021 & -1.113 \\
GK-17 & 1469 & 0.399 & -0.610 \\
GK-5 & 979 & 0.204 & -1.311 \\
\hline
\end{tabular}

saturation of the M-1 ground water with anhydrite over a month (see Fig. 7) (Kopylova et al., 2014).

Bearing in mind the specific features of the new type of hydrogeochemical precursor, we will consider the variation in the saturation of water with anhydrite and barite in the thermal waters of the Verkhnyaya Paratunka wells, which also belong to set III (see Tables 3, 4). It is seen that the passage from ultrafresh to brackish waters entails, in addition to increasing temperature of ground waters and increasing mineral content, and thus, an increasing time of interaction in the water-rock system, also the saturation of water with anhydrite and barite, and reaching an equilibrium between water and barite, thus indicating possible secondary mineral generation of sulfates in the set III waters. Naumov and Sergeeva (2015) studied the Verkhnyaya Paratunka wells to find the deposition of solid precipitate, which is dominated by variously hydrated sulfates accompanied by silica and alumosilicates.

The absence of any well-pronounced hydrogeochemical precursors in the waters of the Verkhnyaya Paratunka wells due to past earthquakes, including the largest earthquake of December 5, 1997 (see Figs. 1, 6), might be caused by the negative effects of switchon/off mode of long-term observations. The sampling data (see Tables 1 and 2) suggest the hypothesis that the waters from the Verkhnyaya Paratunka wells were sampled during a special phase of their compositional evolution, viz., in the zone where the Paratunka graben blocky structure was moderately open at an approximate depth of $1 \mathrm{~km}$, as hydrothermal waters were coming from the zone of a reducing geochemical environment that seems to have an originally hydrosulfide composition with the presence of lithium, fluorine, and boron. Calculations showed that the water from these wells is highly saturated with sulfate minerals, as far as barite (see Table 4).

It has been noted that the Verkhnyaya Paratunka wells are operated in a switch-on/off mode and the effects due to large earthquakes were either absent from the variation of water composition or else were very low. One convincing example of precursor occurrence in a water of set III is furnished by the M-1 well, which is a flowing well. Water discharge in the M-1 well, as well as in the GK-1 and G-1 wells (set II), was in a freely flowing mode, with hydrogeochemical pre- cursors being apparent in these waters during the precursory periods before large earthquakes (Khatkevich and Ryabinin, 2004). The above analysis of conditions for the formation and geochemical aspect of sulfate waters in set III suggests that these waters, hence the Verkhnyaya Paratunka wells, might supply at least as much information relevant to the search for hydrogeochemical precursors as do the saline chloride waters in the zone of retarded water exchange (the GK-1 and G-1 wells, set II), provided the conditions are met for their natural hydrodynamic regime.

\section{CONCLUSIONS}

We used the fundamental patterns in the formation of secondary hydrogenic mineral assemblages that successively replace each other in different geochemical environments (Shvartsev, 2008; Shvartsev et al., 2007) to demonstrate new possibilities in the analysis of permanent water discharges used in the search for hydrogeochemical precursors, depending on the saturation of ground water with primary and secondary rock-forming minerals.

We considered the hydrogeochemical features of ground water at the permanent water discharges in the Petropavlovsk Test Site and classified them incorporating physicochemical parameters and local geology, that is, occurrence in different hydrodynamic water exchange zones, host-rock composition, and the character of the circulation. The determination of genetic relationships between the identified types of ground water at different stages of formation of their chemical compositions, and geochemical types of weathering, the time of interaction between water and rocks, and the depth of water filtration in relation to continuous observations provide new possibilities for estimating the information to be acquired from wells and springs in the search for and study of seismicity-induced geochemical effects.

Individual water discharges were studied to find changes in the saturation of ground water with secondary minerals over time. It was found that large earthquakes with magnitudes 7 or greater that were accompanied by shaking of intensity $I=\mathrm{V}-\mathrm{VI}$ resulted in the saturation of ground water with secondary minerals. The saturation of ground water with secondary minerals occurs in a less-pronounced manner during the 
precursory periods of such earthquakes compared with the effect of increasing saturation when acted upon by seismic waves.

A feasibility study has been carried out to show the necessity of continuous hydrogeochemical observations at the Verkhnyaya Paratunka wells, which should be allowed to flow freely.

\section{ACKNOWLEDGMENTS}

This work was carried out in the framework of the planned topics of scientific research of the KF GS RAS (registered as nos. AAAA-A16-116070550057-7 and AAAA-A16-116070550059-1).

\section{REFERENCES}

Fedotov, S.A., Gusev, A.A., Chernysheva, G.V., and Shumilina, L.S., The Benioff zone of Kamchatka: Geometry, the locations of earthquake hypocenters, and the relationships to volcanism, Vulkanol. Seismol., 1985, no. 4, pp. 91-107.

Garrels, R. and Christ, Ch., Solutions, Minerals, and Equilibria, New York: Harper and Row, 1965.

Geologiya SSSR. Kamchatka, Kuril'skie $i$ Komandorskie ostrova. Geologicheskoe opisanie (The Geology of the USSR. Kamchatka, Kuril Is., and the Commander Is.: A Geological Description), vol. 31, Moscow: Nedra, 1964.

Gidrogeologiya SSSR, vol. 29, Kamchatka, Commander and Kuril Islands, Moscow: Nedra, 1972.

Khatkevich, Yu.M. and Ryabinin, G.V., Hydrogeochemical studies in Kamchatka, in Kompleksnye seismologicheskie i geofizicheskie issledovaniya Kamchatki (Multidisciplinary Seismological and Geophysical Studies in Kamchatka), Petropavlovsk-Kamchatskii: Kamchatskii Pechatnyi Dvor, 2004, pp. 96-112.

Kiryukhin, A.V., Manukhin, Yu.F., Fedorov, S.A., et al., Geofluids in the Avachinsky-Koryaksky volcanogenic basin, Kamchatka, Geoekologiya. Inzhenernaya Geologiya. Gidrogeologiya. Geokriologiya, 2015, no. 4, pp. 306-320.

Kopylova, G.N., An analysis of seismicity effects on the behavior of Pinachevo, Kamchatka thermal discharges: The 1979-1988 observations, Vulkanol. Seismol., 1992, no. 2, pp. 3-18.

Kopylova, G.N. and Boldina, S.V., Anomalous changes in the chemical composition of ground water in relation to the March 2, 1992 earthquake in Kamchatka $\left(\mathrm{M}_{\mathrm{w}}=6.9\right)$, Geofizicheskie Issledovaniya, 2012, vol. 13, no. 1, pp. 39-49.

Kopylova, G.N., Sugrobov, V.M., and Khatkevich, Yu.M., Earthquake-induced variations in the operation of springs and hydrogeological wells in the Petropavlovsk Test Site, Kamchatka, Vulkanol. Seismol., 1994, no. 2, pp. 53-70.

Kopylova, G.N., Kopylova, Yu.G., and Guseva, N.V., On the genesis and mechanisms responsible for hydrogeochemical anomalies in the variation of ground water compositions due to seismicity, in Materialy regional'noi nauchnoi konferentsii "Vulkanizm I svyazannye s nim protsessy”, posvyashchennoi Dnyu vulkanologa (Proc. regional conf. "Volcanism and Related Processes" devoted to Volcanologist's Day), March 2728, 2014, Petropavlovsk-Kamchatskii: IViS DVO RAN, 2014, pp. 181-186.

Manukhin, Yu.F., On water exchange zones in geothermal areas of Kamchatka, in Vulkanizm i glubiny Zemli (Volcanism and the Earth's Interior), Moscow: Nauka, 1971, pp. 219-224.

Manukhin, Yu.F. and Vorozheikina, L.A., The hydrogeology of the Paratunka hydrothermal system and the conditions of its generation, in Gidrotermal'nye sistemy i termal'nye polya Kamchatki (Hydrothermal Systems and Thermal Fields in Kamchatka), Vladivostok: DVNTs AN SSSR, 1976, pp. 143-178.

Naumov, A.V. and Sergeeva, A.V., Gypsum in the VerkhneParatunka field of thermal waters, in Problemy kompleksnogo geofizicheskogo monitoringa Dal'nego Vostoka Rossii (Problems in the Geophysical Monitoring of the Russian Far East), Proc. 5th sci. conf., PetropavlovskKamchatskii, September 27 to October 3, 2015, Chebrov, V.N., Editor-in-Chief, Obninsk: GS RAN, 2015, pp. 86-90.

Polyak, B.G., Vakin, E.A., and Ovchinnikova, E.I., Gidrogeotermicheskie usloviya vulkanicheskogo raiona Kamchatki (g. Petropavlovsk-Kamchatskii) (Hydrogeothermal conditions of a volcanic area in Kamchatka (Petropavlovsk-Kamchatskii)), Moscow: Nauka, 1965.

Shvartsev, S.L., Gidrogeokhimiya zony gipergeneza (The Hydrogeochemistry of the Hypergenesis Zone), Moscow: Nedra, 1998.

Shvartsev, S.L., Fundamental mechanisms of interaction in a system: Rock and its internal geological evolution, Litosfera, 2008, no. 6, pp. 3-24.

Shvartsev, S.L., Ryzhenko, B.N., Alekseev, V.A., et al., Geologicheskaya evolyutsiya i samoorganizatsiya sistemy voda-poroda (Geological Evolution and Self-organization of the Water-Rock System), vol. 2, The WaterRock System in the Conditions of a Hypergenesis Zone, Novosibirsk: SO RAN, 2007.

Zverev, V.P., Rol' podszemnykh vod v migratsii khimicheskikh elementov (The Role of Ground Water in the Migration of Chemical Elements), Moscow: Nedra, 1982.

Translated by A. Petrosyan 